カンファレンスルーム

CASE 9

一高齢のメニエール病の既往がある良性発作性頭位めまい症症例一

今井 貴夫・佐藤 崇

Elderly case with benign paroxysmal positional vertigo following

Meniere disease

Takao Imai, Takashi Sato

Department of Otorhinolaryngology - Head and Neck Surgery, Osaka University Graduate School of Medicine

症例 : 76歳, 男性

主訴：繰り返す回転性めまい発作。

家族歴：特記すべきことなし。

既往症：30年前 脊髄炎。

服薬歴：イソソルビド内服中。

現病歴： 3 年前より月に 1,2 回の回転性めまい 発作が出現。めまい発作時には 1 日中寝込んでしま う。そのころより右耳鳴（キーン）も出現。紹介元 の病院にてイソソルビドの内服治療を行うもめまい 発作の頻度が減少せず当科紹介となった。

現症と診療経過：

$<$ 初診 $>$

$\mathrm{S}$ ：繰り返す回転性めまい発作。

$\mathrm{O}$ : 両鼓膜異常なし, 右感音難聴 (図 1), 自発 眼振 $(-)$, 頭振後眼振 $(-)$, 頭位 - 頭位変換眼振 $(-)$

A : メニエール病, 前庭性片頭痛, 前庭性発作症 (vestibular paroxysmia)

$\mathrm{P}$ ：自宅眼球運動撮影装置の貸し出し。25日後に 当科に検査入院し, 内耳造影 MRI, 蝸電図検査, グリセロールテスト，カロリック検査を予定。

大阪大学大学院医学系研究科耳鼻咽喉科・頭頸部外科
$<25$ 日後検査入院 $>$

$\mathrm{S} ：$ こ 25 日間で 7 回の回転性めまい発作があっ た。

$\mathrm{O}$ ：内耳造影 MRI：右螖牛, 前庭に水腫 $(+)$, 左は水腫 $(-)($ 図 2$)$

螖電図検查: SP/AP 比 右 0.426 , 左 0.514

グリセロールテスト：両側陰性

カロリック検査：右 CP 50\%

自宅眼球運動撮影装置にてめまい発作時に右向き の水平性眼振が記録されていた（図 $3 \mathrm{~A}$ )。

$\mathrm{A}:$ 右メニエール病

$\mathrm{P}$ ：イソソルビド内服治療を継続し, 改善なけれ ば内リンパ囊開放術を考慮。

<初診より 4 力月後 $>$

退院後もめまい発作が持続するため, 全身麻醉下 に右内リンパ囊開放術を施行。

手術より 2 カ月後にめまい発作が 1 度あったが, 以後, 4 年間, めまい発作がなかった。

$<$ 手術より 4 年 8 力月後の再診(1) $>$

S：1力月前より毎日，10分ほど続く回転性めま い発作あり。

$\mathrm{O}$ : 自発眼振 $(-)$, 頭振後眼振 $(-)$, 頭位 $\cdot$ 頭 位変換眼振 $(-)$
$\mathrm{A}$ ：右メニエール病のめまい発作の再発
$\mathrm{P}$ ：イソソルビド処方, 自宅眼球運動撮影装置の 
貸し出し

$<$ 再診(1)より 2 週間後再診 $>$

S：10分ほど続く軽いめまい発作が 2 日に一度あ る。

$\mathrm{O}$ ：診察時には頭位・頭位変換眼振 $(-)$ 。自宅 眼球運動撮影装置にて, 右後半規管型良性発作性頭 位めまい症（BPPV）（半規管結石症）に典型的な, 減衰する上眼瞼向き，右回旋の垂直回旋混合性眼振 が記録されていた（図 3 B）。この眼振記録時のこ とを聞くと，臥位になったときにめまいが生じ，臥 位にて記録した，とのことであった。

周波数 $(\mathrm{Hz})$

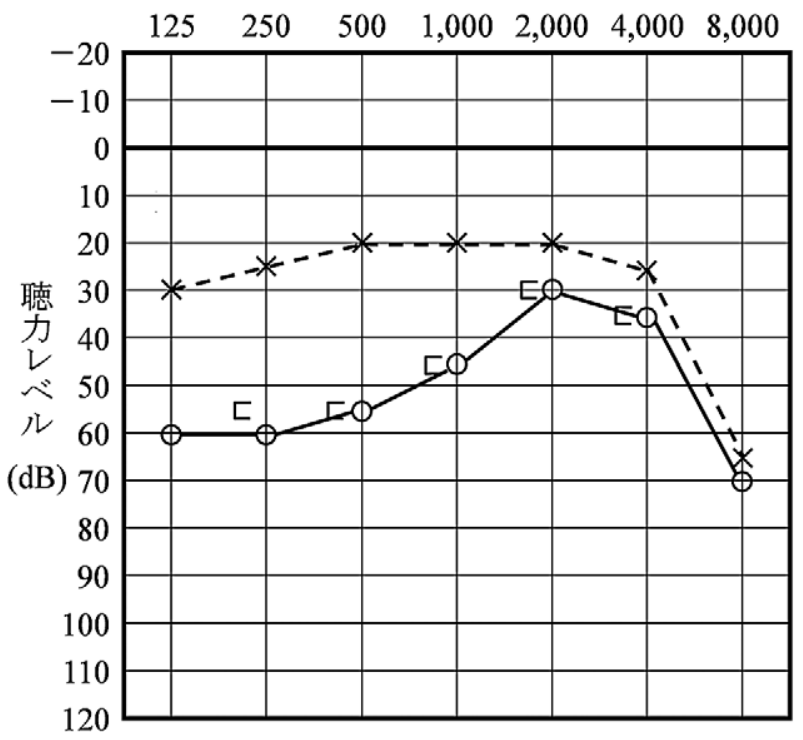

図 1 初診時の純音聴力検査 右低音部の閾值上昇を認める。
A：右後半規管型 BPPV（半規管結石症）
P：Epley 法を施行後, Brandt-Daroff 法を指導

し，自宅で行うよう指示

$<$ 再診(1)より 4 週間後再診 $>$

$\mathrm{S}: 2$ 週間前よりめまい発作消失。

$\mathrm{O}$ ：自発眼振 $(-)$, 頭振後眼振 $(-)$, 頭位 - 頭 位変換眼振 $(-)$ 。
A：右後半規管型 BPPV（半規管結石症）治癒。
P : Brandt-Daroff 法終了。

\section{2. 症例の解説}

本症例では右メニエール病の既往があったこと， めまい発作の持続時間が10分ほどであったことよ り, 内リンパ囊開放術後のめまい発作をメニエール 病のめまい発作の再発と考えた。しかし，めまい発 作時の眼振を自宅眼球運動撮影装置にて患者自身に 撮影してもらったところ, 右後半規管型 BPPV（半 規管結石症）に典型的な眼振が映っており，右後半 規管型 BPPV（半規管結石症）と診断した。一般的 にBPPVのめまい発作の持続時間は短いが，まれ に長い持続時間を訴える場合があり，特に高齢者で はその傾向が見られる。

3. 診療のピットホールとコッ, メッセージ 繰り返すめまい発作を主訴とする疾患として, メ ニエール病, 前庭性片頭痛や前庭性発作症に加え, BPPV も考えられる。BPPVでは患者が若い場合は 特定の頭位変換やめまい頭位を取ることにより，め まい発作が生じることに気付いている場合が多いの で，BPPVに典型的な病歴が聴取でき，診断が容易
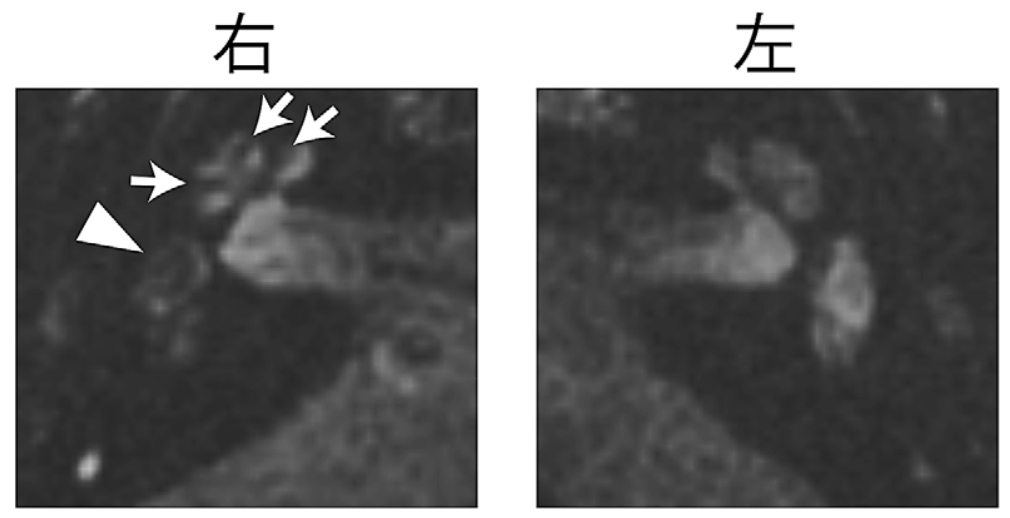

図2 内耳造影 MRI（2 D-FLAIR 画像）

右蝸牛 (矢印), 右前庭（矢頭）に低信号領域を認め, 右蝸 牛と右前庭の内リンパ水腫の存在が示唆される。 
(A)
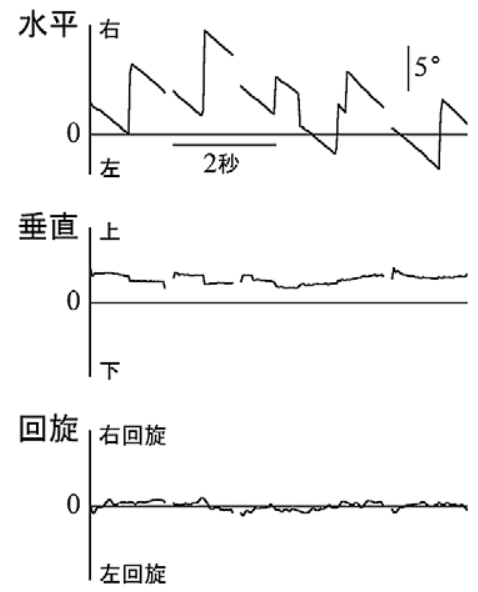

(B)
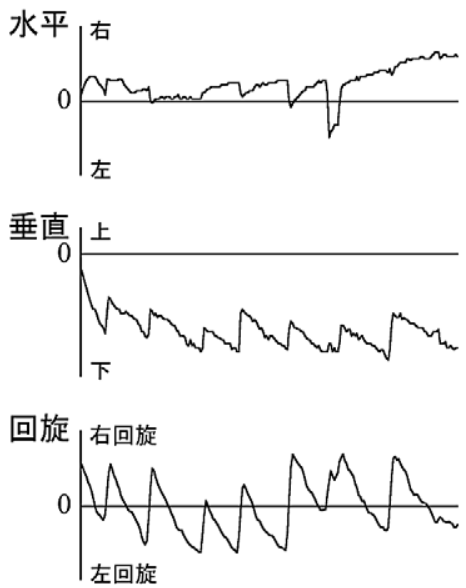

図3 自宅眼球運動撮影装置にて撮影された眼振

(A) 手術前のめまい発作時の眼振 右向きの水平性眼振が観察された。

（B）手術後のめまい発作時の眼振

上眼瞼向き, 右回旋の垂直回旋混合性眼振が観察され た。

である。しかし，高齢の BPPV 患者の場合はどの ような動きでめまい発作が生じているのかに気付い ていない場合があり，また，めまい発作の持続時間 に回転性めまい後のふらつきも加えてしまい，長い 持続時間を訴えることがある。10分以上持続する繰 り返すめまい発作を訴える場合、メニエール病を第 一に疑うべきであるが，メニエール病に対する治療 に抵抗性の場合や患者が高齢である場合は BPPV の可能性も考慮すべきである。我々の施設のように 自宅眼球運動撮影装置があれば確実に診断できる が，そうでない場合は BPPVの可能性を念頭に置
き問診を行う。BPPVに典型的な病歴が得られない 場合は, 寝ているときのめまい発作の有無, めまい 発作が生じる時間带を問診する。BPPVでは寝返り でめまいが起こるので臥位の時にめまい発作が生じ ることが多く, また, 寝起きの動作でもめまいが起 こるので, 就寝時刻や起床時刻にめまい発作が生じ ることが多い。

高齢の BPPV 患者からは典型的な BPPV の病歴 が聴取できず, メニエール病のめまい発作の性状を 訴える場合があることを念頭に置いておく。 